\title{
HEMOPHAGOCYTIC LYMPHOHISTIOCYTOSIS SECONDARY TO RHEUMATOID ARTHRITIS
}

\author{
L. Gautam Mukesh ${ }^{1}$, K. Vengadakrishnan ${ }^{2}$, A. K. Koushik ${ }^{3}$
}

\section{HOW TO CITE THIS ARTICLE:}

L. Gautam Mukesh, K. Vengadakrishnan, A. K. Koushik. "Hemophagocytic Lymphohistiocytosis Secondary to Rheumatoid Arthritis". Journal of Evolution of Medical and Dental Sciences 2014; Vol. 3, Issue 67, December 04; Page: 14531-14536, DOI: 10.14260/jemds/2014/3949

\begin{abstract}
Hemophagocytic lymphohistiocytosis (HLH), also known as hemophagocytic syndrome (HPS), is a rare, life threatening, hematologic disorder manifested by clinical findings of extreme inflammation, unregulated immune activation and organ damage including cytopenias, hepatitis, coagulopathy and central nervous system damage. An exemplary case of adult HLH is presented here, illustrating the clinical features, history and treatment of this aggressive and fatal disease. A 30 year old male presented with fever and joint pains, and was found to have HLH triggered by rheumatoid arthritis. He responded well to the treatment and remains in remission with regular follow up. Tissue biopsy (bone marrow, lymph node or liver) is done to look for hemophagocytosis, but presence of hemophagocytosis is not definitely required in diagnosis of HLH. Once the diagnosis is confirmed, chemo immunotherapy should be initiated rapidly to induce remission.
\end{abstract}

KEYWORDS: Hemophagocytic lymphohistiocytosis, Macrophage activation syndrome, Rheumatoid arthritis.

INTRODUCTION: Hemophagocytic syndrome (HLH) was first described in 1952 by James Farquhar and Albert Clarieaux, who encountered 2 siblings with an unrecognized complex of cytopenias, hepatosplenomegaly and unremitting fevers.[1]

HLH can be classified according to the underlying etiology in to either primary (genetic) or secondary (acquired). The primary can be of 2 sub-groups. One being the FAMILIAL form which occurs in young children as a genetic disorder with autosomal recessive inheritance, responsible gene mapped to the long arms of chromosome 9 and 10 and the other being IMMUNE DEFICIENCIES like chediak-higashi syndrome (CHS 1), Griscelli syndrome (GS 2) and X-linked proliferative syndrome (XLP). Secondary HLH can occur at any age group. It was first described by Risdall and colleagues in adults with a viral infection after organ transplantation. It is associated with infections (eg, EpsteinBarr virus (EBV), cytomegalovirus, herpes simplex virus, avian influenza, rhematologic diseases (eg, systemic lupus erythamatosis, Kawasaki syndrome, adult-onset Still's disease, rheumatoid arthritis and others, malignancy (eg, natural killer [NK]- cell leukemia, peripheral T-cell lymphoma, EBV in T cell lymphoma, B-cell lymphoma, and a variety of other lymphomas, acquired immune deficiency state (eg, after organ transplantation), and pharmacotherapy.

The macrophage activation syndrome (MAS), is a special form of HLH with auto immune diseases, especially juvenile rheumatoid arthritis (JRA) or adult onset Still's disease and others. [2,3] Patients with MAS present with defective NK cell function and can have decreased expression of perforin or SAP, mimicking the defects associated with FHLH and XLP, respectively.[4] MAS can be triggered by infections most commonly viruses, but drugs have also been implicated.

CASE REPORT: A 30 year old male presented with history of fever since 9 months, facial swelling since 3 months, multiple joint pains (shoulder, knee, ankle and small joints of legs) for a month, loss 


\section{CASE REPORT}

of weight (Approx. $23 \mathrm{kgs}$ in 9 months) and generalized weakness. He was previously healthy and taking no regular medications. His family history was unremarkable. The physical examination revealed a temperature of $38.5^{\circ} \mathrm{C}$, presence of pallor, facial puffiness, periorbital edema, bilateral sub mandibular and sub mental region swelling. His abdomen was soft non-tender with focal edema, sub umbilical induration and splenomegaly palpable $3 \mathrm{~cm}$ below the costal margin. Rest of his physical examination was unremarkable. His initial blood work up revealed Bicytopenia, elevated ESR, LDH Triglyceride levels and hyponatremia, serum ferritin levels was elevated $5257 \mathrm{mcg} / \mathrm{l}$. (TABLE: 1)

Bone marrow biopsy and aspiration failed to reveal hemophagocytosis. USG cheek revealed cellulitis of both cheeks (left>right). CT thorax plain revealed diffuse subcutaneous soft tissue edema, involving bilateral anterior chest wall and sub mediastinum. USG abdomen revealed splenomegaly with subcutaneous edema in the anterior abdominal wall. Incisional biopsy from anterior abdominal wall showed mild hyperkeratosis. CD4, CD8 counts were 99/mcl and 146/mcl respectively suggesting immunosuppression. Connective tissue work up showed positive for RA factor and raised CRP.

He was diagnosed to have HLH which was triggered by Rheumatoid arthritis. He was started on steroids as monotherapy and responded well to the treatment and was in remission with regular follow up. Investigations at the time of discharge. (TABLE; 2)

\begin{tabular}{|l|l|}
\hline INVESTIGATIONS & \multicolumn{1}{|c|}{ VALUES } \\
\hline WBC & $2,900 / \mathrm{cmm}$ \\
\hline Hemoglobin & $9.9 \mathrm{gm} \%$ \\
\hline Platelet count & $1.5 \mathrm{lakhs} / \mathrm{cmm}$ \\
\hline Sr. Sodium & $126 \mathrm{meq} / \mathrm{dl}$ \\
\hline Urine spot Na & $95 \mathrm{mmo} / \mathrm{lt}$ \\
\hline SGOT & $84 \mathrm{IU} / \mathrm{lt}$ \\
\hline SGPT & $30 \mathrm{IU} / \mathrm{lt}$ \\
\hline Albumin & $2.6 \mathrm{gm} \%$ \\
\hline LDH & $1386 \mathrm{IU} / \mathrm{lt}$ \\
\hline Triglycerides & $283 \mathrm{mg} / \mathrm{dl}$ \\
\hline CPK & $233 \mathrm{IU} / \mathrm{lt}$ \\
\hline Sr. Amylase & $219 \mathrm{IU} / \mathrm{lt}$ \\
\hline Sr. Ferritin & $5257 \mathrm{mcg} / \mathrm{l}$ \\
\hline ESR & $40 \mathrm{~mm} / \mathrm{hour}$ \\
\hline Fibrinogen & $357 \mathrm{mg} / \mathrm{dl}$ \\
\hline CD4 & $99 / \mathrm{mcl}$ \\
\hline CD8 & $146 / \mathrm{mcl}$ \\
\hline CRP & $4.8 \mathrm{mg} / \mathrm{dl}$ \\
\hline Rheumatoid factor & Positive \\
\hline \multicolumn{2}{|l|}{ TABLE 1} \\
\hline
\end{tabular}


CASE REPORT

\begin{tabular}{|l|c|c|}
\hline INVESTIGATIONS & ON ADMISSION & $\begin{array}{c}\text { AFTER 1 WEEK } \\
\text { USE OF STEROIDS }\end{array}$ \\
\hline Hemoglobin & 9.9 & 9.6 \\
\hline WBC & 2900 & 8200 \\
\hline Platelets & 1.50 & 2.89 \\
\hline Sodium & 126 & 143 \\
\hline Albumin & 2.6 & 3.6 \\
\hline Cholesterol & 132 & 185 \\
\hline Triglycerides & 283 & 177 \\
\hline HDL & 12 & 45 \\
\hline LDL & 89 & 123 \\
\hline & TABLE 2 & \\
\hline
\end{tabular}

DISCUSSION: HLH is a rare, life threatening hyperinflammatory syndrome, caused by severe hypercytokinemia due to a highly stimulated but ineffective immune process. A hall mark of HLH, in both genetic as well as in acquired cases, is absent or impaired activity of natural killer (NK) and cytotoxic T-cells (CTL). More recent work with whole gene-analysis expression has shown down regulation of pro apoptotic signals and genes related to innate and adaptive immune responses, along with the up regulation of genes coding for proinflammatory cytokines and antiapoptotic factors. In patients with FHLH, NK cell numbers are within normal range and the defect is usually persistent. Patients with acquired HLH can show low NK cell numbers and usually have decreased NK cell function with active disease. After treatment the function of NK cells reverts to normal. Characteristic laboratory findings include increased levels of triglycerides, ferritin, bilirubin, transaminases and LDH and a low fibrinogen. ${ }^{[5-8]}$

High concentrations of inflammatory cytokines[9,10] and organ infiltration by activated lymphocytes and histiocytes can explain all symptoms of hemophagocytic syndrome. Interleukin-1 and interleukin- 6 induce fever and, high levels of tumor necrosis factor TNF alpha and interferon gamma cause pancytopenia, rather than hematophgocytosis. The inhibition of lipoprotein lipase by TNF alpha leads to elevated triglycerides.

Activated macrophages secrete ferritin as well as plasminogen activator resulting in high levels of plasmin and hyperfibrinolysis. It is implicated that the source for the high concentrations of the alpha- chain of the soluble interleukin-2 receptor is activated lymphocytes. Lastly hepatoslenomegaly, increased bilirubin and liver enzyme along with neurological symptoms are the consequence of organ damage due to infiltration by activated lymphocytes and histiocytes. The diagnostic criteria are shown in chart 1 . Five out of eight criteria are necessary to make a diagnosis of HLH. 


\section{Chart 1: Diagnostic criteria for hemophagocytic syndrome:}

\section{Clinical criteria}

1. Fever

2. Splenomegaly

Biochemical criteria

3. Cytopenia ( affecting atleast 2 of 3 lineages in the peripheral blood)

3a. Hemoglobin $<90 \mathrm{~g} / \mathrm{L}$

3b. Platelets $<1$ lakh $/ \mathrm{cmm}$

3c. Neutrophils $<1000 / \mathrm{cmm}$

4. Hypertriglyceridemia or hypofibrinogenemia

4a. Fasting triglycerides $>265 \mathrm{mg} / \mathrm{dL}$

4b. Fibrinogen $<1.5 \mathrm{~g} / \mathrm{L}$

5. Ferritin $>500 \mathrm{mcg} / \mathrm{L}$

6. Low or absent natural killer cell activity ( in accordance with criteria of a local reference laboratory)

7. Soluble CD25 > 2400U/ml

Histopathological criteria

8. Hemophagocytosis in bone marrow, spleen or lymph nodes (no evidence of malignancy)

The diagnosis is dependent on 5 of the 8 criteria being met. Adapted from Henter et al [2]

Hemophagocytosis by macrophages can occur as an isolated phenomenon in many conditions such as hemolytic anemia, metabolic diseases or malignancies. The hemophagocytosis in hemophagocytic lymphohistiocytosis (HLH) is a constituent of sepsis like clinical syndrome due to severe hypercytokinemia as the consequence of highly stimulated but ineffective immune response. Hemophagocytosis is a histopathological finding in bone marrow, spleen and lymph nodes and occasionally the central nervous system ${ }^{[11,12]}$ and also skin. Finding hemophagocytosis can suggest $\mathrm{HLH}$, but is neither necessary nor sufficient to make the diagnosis. Biopsies fail to demonstrate hemphagocytes in approximately one third of patients. Other new disease markers which are implicated in HLH, secreted by activated macrophages are beta 2 microglobulin, MIP-1alpha and soluble CD163, the hemoglobin scavenger receptor.

In the absence of arthritis in macrophage activation syndrome (MAS), some criteria may be helpful to differentiate MAS from other forms of HLH such as very high C-reactive protein, only moderate cytopenias, reduced erythropoiesis and a increased level of interleukin-1beta.[13]

It is not a dictum that all patients require full protocol treatment. Patients with HLH associated with rheumatological diseases (MAS) often respond well to corticosteroids alone or corticosteroids with cyclosporine A and/or intravenous immunoglobin.[14] Cyclosporine A has been successfully used and shown promising results in the treatment of MAS. TNF-inhibiting agents, IL-1 


\section{CASE REPORT}

inhibitors and anti IL- 6 antibodies are the other agents that have been used effectively in treatment of this disorder. HLH relapse and increased severity of disease can be assessed with deterioration of liver function and blood counts, as well as increase in serum ferritin, sCD 25 and sCD 163 levels.[15]

CONCLUSION: HLH is an uncommon, aggressive and life threatening disease which can be triggered secondarily by various causes, most commonly infections, auto immune conditions and malignancy leading to a fatal outcome if not treated promptly. Thus, early recognition and treatment of this disorder is necessary to decrease associated morbidity and mortality. Acquired HLH usually responds well to steroids.

The criteria for HLH cannot be strictly followed. In our case report we had only 4 out of 8 criteria suggested by Henter et al (High ferritin, High triglycerides, Fever, Splenomegaly). Still it was a high possibility of HLH as per very high ferritin, bicytopenia (Though not meeting the criteria), elevated liver enzymes and evidence of immune suppression as supported by low CD4 count. HLH is often a delayed diagnosis if we strictly follow the criteria. Blind application of the criteria in conditions such as severe sepsis will tend to over diagnose HLH and high clinical suspicion is required along with specific abnormalities in lab parameters as discussed above.

\section{REFERENCES:}

1. Favara B. Hemophagocytic lymphohistiocytosis: a hemophagocytic syndrome. Semin Diagn Pathol 1992; 9: 63-74.

2. Henter JI, Arico M, Elinder G, Imashuku S, Janka G. Familial hemophagocytic lymphohistiocytosis. Primary hemophagocytic lymphohistiocytosis. Hematol Oncol Clin North Am 1998; 12: 417-33.

3. Schneider EM, Lorenz I, Muller-Rosenberger M, Steinbach G, Kron M, Janka-Schaub GE. Hemophagocytic lymphohistiocytosis is associated with deficiencies of cellular cytolysis but normal expression of transcripts relevant to killer-cell- induced apoptosis. Blood 2002; 100: 2891-8.

4. Henter JI, Elinder G, Soder O, Hansson M, Andersson B, Andersson U. Hypercytokinemia in familial hemophagocytic lymphohistiocytosis. Blood 1991; 78: 2918-22.

5. Grom AA, Villanueva J, Lee S, Goldmuntz EA, Passo MH, Filipovich A. Natural killer cell dysfunction in patients with systemic-onset juvenile rheumatoid arthritis and macrophage activation syndrome. J Pediatr 2003; 142: 292-6.

6. Wulffraat NM, Rijkers GT, Elst E, Brooimans R, Kuis W. Reduced perforin expression in systemic juvenile idiopathic arthritis is restored by autologous stem-cell transplantation. Rheumatology (Oxford) 2003; 42: 375-9.

7. Takei M, Ishiwata $\mathrm{T}$, Mitamura $\mathrm{K}$ et al. Decreased expression of signalling lymphocyticactivation molecule-associated protein (SAP) transcripts in $\mathrm{T}$ cells from patients with rheumatoid arthritis. Int Immunol 2001; 13: 559-65.

8. Hibi S, Ikushima S, Fujiwara F et al. Serum and urine beta- 2-microglobulin in hemophagocytic syndrome. Cancer 1995; 75: 1700-5.

9. Teruya-Feldstein J, Setsuda J, Yao X et al. MIP-1alpha expression in tissues from patients with hemophagocytic syndrome. Lab Invest 1999; 79: 1583-90.

10. Farquhar JW, Claireaux AE. Familial haemophagocytic reticulosis. Arch Dis Child. 1952; 27: 519525. 


\section{CASE REPORT}

11. Cortis E, Insalaco A. Macrophage activation syndrome in juvenile idiopathic arthritis. Acta Paediatr Suppl. 2006; 95: 38-41.

12. Parodi $A$, Davì $S$, Pringe $A B$ et al. Macrophage activation syndrome in juvenile systemic lupus erythematosus: a multinational multicenter study of thirty-eight patients. Arthritis Rheum. 2009; 60: 3388-3399.

13. You CR, Kim HR, Yoon $\mathrm{CH}$ et al. Macrophage activation syndrome in juvenile rheumatoid arthritis successfully treated with cyclosporine A: a case report. J Korean Med Sci. 2006; 21: 1124-1127.

14. Lin TF, Ferlic-Stark LL, Allen CE et al. Rate of decline of ferritin in patients with hemophagocytic lymphohistiocytosis as a prognostic variable for mortality. Pediatr Blood Cancer. 2011; 56: 154155.

15. Lambotte O, Cacoub P, Costedoat N, Le Moel G, Amoura Z, Piette JC. High ferritin and low glycosylated ferritin may also be a marker of excessive macrophage activation. J Rheumatol 2003; 30: 1027-1028.

\section{AUTHORS:}

1. L. Gautam Mukesh

2. K. Vengadakrishnan

3. A. K. Koushik

\section{PARTICULARS OF CONTRIBUTORS:}

1. First Year Post Graduate, Department of General Medicine, Sri Ramachandra Medical College, Chennai.

\section{NAME ADDRESS EMAIL ID OF THE CORRESPONDING AUTHOR:}

Dr. K. Vengadakrishnan, Department of General Medicine, SRMC, Porur, Chennai-600116.

Email: drkvk1975@gmail.com

Date of Submission: 22/11/2014. Date of Peer Review: 24/11/2014. Date of Acceptance: 28/11/2014. Date of Publishing: 04/12/2014. 